Archived version from NCDOCKS Institutional Repository http://libres.uncg.edu/ir/asu/

\title{
Appalachỉan
}

B O O N E, N O R T H C A R O L I N A

\section{Influence Of Vitamin C Supplementation On Oxidative And Immune Changes After An Ultramarathon}

\author{
By: David C. Nieman, Dru A. Henson, Steven R. McAnulty, Lisa McAnulty, Nathaniel S. Swick, \\ Alan C. Utter, Debra M. Vinci, Shannon J. Opiela, and Jason D. Morrow
}

\begin{abstract}
The purpose of this randomized study was to measure the influence of vitamin $C$ ( $n=15$ runners) compared with placebo ( $n=13$ runners) supplementation on oxidative and immune changes in runners competing in an ultramarathon race. During the 7-day period before the race and on race day, subjects ingested in randomized, double-blind fashion $1,500 \mathrm{mg} /$ day vitamin $\mathrm{C}$ or placebo. On race day, blood samples were collected $1 \mathrm{~h}$ before race, after $32 \mathrm{~km}$ of running, and then again immediately after race. Subjects in both groups maintained an intensity of $75 \%$ maximal heart rate throughout the ultramarathon race and ran a mean of $69 \mathrm{~km}$ (range: 48$80 \mathrm{~km}$ ) in $9.8 \mathrm{~h}$ (range: 5-12 h). Plasma ascorbic acid was markedly higher in the vitamin C compared with placebo group prerace and rose more strongly in the vitamin $C$ group during the race (postrace: $3.21 \pm 0.29$ and $1.28 \pm 0.12 \mu \mathrm{g} / 100 \mu \mathrm{l}$, respectively, $\mathrm{P}<0.001)$. No significant group or interaction effects were measured for lipid hydroperoxide, F2-isoprostane, immune cell counts, plasma interleukin (IL)-6, IL-10, IL-1-receptor antagonist, or IL-8 concentrations, or mitogen-stimulated lymphocyte proliferation and IL-2 and IFN- $\gamma$ production. These data indicate that vitamin $C$ supplementation in carbohydrate-fed runners does not serve as a countermeasure to oxidative and immune changes during or after a competitive ultramarathon race.
\end{abstract}

David C. Nieman, Dru A. Henson, Steven R. McAnulty, Lisa McAnulty, Nathaniel S. Swick, Alan C. Utter, Debra M. Vinci, Shannon J. Opiela, and Jason D. Morrow. (2002). Influence of vitamin C supplementation on oxidative and immune changes after an ultramarathon. Journal of Applied Physiology 2002 92:5, 1970-1977. Publisher version of record available at: https://doi.org/10.1152/japplphysiol.00961.2001 


\title{
Influence of vitamin $\mathrm{C}$ supplementation on oxidative and immune changes after an ultramarathon
}

\author{
DAVID C. NIEMAN, ${ }^{1}$ DRU A. HENSON,${ }^{1}$ STEVE R. MCANULTY,${ }^{1}$ \\ LISA MCANULTY, ${ }^{1}$ NATHANIEL S. SWICK, ${ }^{1}$ ALAN C. UTTER, ${ }^{1}$ \\ DEBRA M. VINCI, ${ }^{1}$ SHANNON J. OPIELA, ${ }^{1}$ AND JASON D. MORROW ${ }^{2}$ \\ ${ }^{1}$ Departments of Health, Leisure, and Exercise Science, and Biology, Appalachian \\ State University, Boone, North Carolina 28608; ${ }^{2}$ Departments of Medicine and \\ Pharmacology, Vanderbilt University School of Medicine, Nashville, Tennessee 37232
}

\begin{abstract}
Nieman, David C., Dru A. Henson, Steve R. McAnulty, Lisa McAnulty, Nathaniel S. Swick, Alan C. Utter, Debra M. Vinci, Shannon J. Opiela, and Jason D. Morrow. Influence of vitamin $\mathrm{C}$ supplementation on oxidative and immune changes after an ultramarathon. J Appl Physiol 92: 1970-1977, 2002. First published February 1, 2002; 10.1152/japplphysiol.00961.2001.-The purpose of this randomized study was to measure the influence of vitamin $\mathrm{C}$ ( $n=15$ runners) compared with placebo ( $n=13$ runners) supplementation on oxidative and immune changes in runners competing in an ultramarathon race. During the 7-day period before the race and on race day, subjects ingested in randomized, double-blind fashion $1,500 \mathrm{mg} /$ day vitamin $\mathrm{C}$ or placebo. On race day, blood samples were collected $1 \mathrm{~h}$ before race, after $32 \mathrm{~km}$ of running, and then again immediately after race. Subjects in both groups maintained an intensity of $\sim 75 \%$ maximal heart rate throughout the ultramarathon race and ran a mean of $69 \mathrm{~km}$ (range: $48-80 \mathrm{~km}$ ) in $9.8 \mathrm{~h}$ (range: 5-12 h). Plasma ascorbic acid was markedly higher in the vitamin $\mathrm{C}$ compared with placebo group prerace and rose more strongly in the vitamin $\mathrm{C}$ group during the race (postrace: $3.21 \pm 0.29$ and $1.28 \pm 0.12 \mu \mathrm{g} / 100 \mu \mathrm{l}$, respectively, $P<$ $0.001)$. No significant group or interaction effects were measured for lipid hydroperoxide, $\mathrm{F}_{2}$-isoprostane, immune cell counts, plasma interleukin (IL)-6, IL-10, IL-1-receptor antagonist, or IL-8 concentrations, or mitogen-stimulated lymphocyte proliferation and IL- 2 and IFN- $\gamma$ production. These data indicate that vitamin $\mathrm{C}$ supplementation in carbohydrate-fed runners does not serve as a countermeasure to oxidative and immune changes during or after a competitive ultramarathon race.
\end{abstract}

interleukins; ascorbic acid; lymphocytes; isoprostanes; lipid hydroperoxide

OF ALL ESSENTIAL NUTRIENTS, vitamin C has generated the greatest interest for its potential influence on immune function and host defense (11). Vitamin $\mathrm{C}$ supplements have been shown to alter many different indexes of human immune responses, and the concentration of vitamin $\mathrm{C}$ is high in activated neutrophils and macrophages $(5,12,32,37,39)$. Vitamin $\mathrm{C}$ also provides in vivo antioxidant protection primarily as an aqueous- phase peroxyl and oxygen radical scavenger and is concentrated in tissues and fluids with a high potential for radical generation (12). In response to physical trauma, vitamin $\mathrm{C}$ exerts a protective effect on neutrophil-mediated cell injury by scavenging reactive oxygen metabolites (9). Free-radical-mediated processes appear to be an important component of exercise-induced muscle and lymphoid tissue damage and inflammation (3).

Production of reactive oxygen species (ROS) during exhaustive exercise is well established $(1,2,25,31,33$, $36,38)$. Several studies have indicated that vitamin $C$ supplementation attenuates exercise-induced oxidative stress, but this is not a consistent finding (2, 29-31, 34, 38). ROS generation and antioxidant status may be linked to immune alterations after exercise, including cell adhesion, inflammation, and lymphocyte proliferation, and conversely, certain immune changes may contribute to oxidative stress $(6,33,35)$. Several studies have produced conflicting data regarding the influence of vitamin $\mathrm{C}$ supplementation on immune changes after heavy exertion, and no data are presently available on how oxidative changes may influence this relationship. Three placebo-controlled investigations have shown that supplemental vitamin $\mathrm{C}$ (500-1,000 mg/day for 7-14 days) has no effect on a wide array of immune changes after intensive endurance exercise of 1 - to 2.5 -h duration $(14,21,28)$. Two other studies with runners competing in the $90-\mathrm{km}$ Comrades Ultramarathon showed an attenuation of postrace changes in serum cortisol, plasma cytokines, and leukocyte subset counts in subjects using vitamin C supplements $(24,26,27)$. However, subjects in the two Comrades studies were not randomized to treatment groups, and carbohydrate intake was not controlled. Carbohydrate ingestion during prolonged and intensive exercise has strong influences on alterations in cortisol, immune cell counts, and anti-inflammatory cytokines (19, 20, 22, 23). Another potential explanation for the disparity in study outcomes is that vitamin 
C supplementation may not influence immunity after exercise until ultradistances are achieved. The purpose of this study was to measure the influence of vitamin C compared with placebo supplementation on oxidative and immune changes in ultramarathoners competing in an ultramarathon race. To improve on previous studies, subjects were randomized to treatment groups, and carbohydrate intake was carefully controlled. We hypothesized that vitamin $\mathrm{C}$ supplementation would attenuate changes in oxidative and immune measures during and after an ultramarathon race.

\section{METHODS}

Subjects. Ultramarathon runners were recruited through a letter of invitation before the April 7, 2001, Umstead Ultramarathon, in Raleigh, North Carolina. The Umstead Ultramarathon is conducted on a $16-\mathrm{km}$ loop that is run five times for the $80-\mathrm{km}$ race. Male and female runners ranging in age from 20 to $70 \mathrm{yr}$ were accepted into the study if they had run at least one competitive ultramarathon and were willing to adhere to all aspects of the research design, including randomization to either the vitamin $\mathrm{C}$ or placebo group. Informed consent was obtained from each subject, and the experimental procedures were in accordance with the policy statements of the institutional review board of Appalachian State University.

Research design. Four to six weeks before the ultramarathon race event, subjects reported to the Appalachian State University human performance laboratory for orientation and measurement of body composition and cardiorespiratory fitness. Basic demographic and training data were obtained through a questionnaire. Runners agreed to avoid the use of large-dose vitamin and/or mineral supplements (above 100\% of recommended dietary allowances), herbs, and medications known to affect immune function for 1 mo before the race. Runners also agreed to avoid ingesting anti-inflammatory medications the day before or during the race. During orientation, a dietitian instructed the runners to follow a diet high in carbohydrates and moderate in vitamin $\mathrm{C}$ during the 7 days before the race event (through use of a food list) and record intake in a food record.

Body composition was assessed from hydrostatic weighing, and maximal oxygen consumption was determined by using a graded maximal protocol adapted for runners as described in earlier studies from our group (19, 21-23). Oxygen uptake and ventilation were measured by using the MedGraphics CPX metabolic system (MedGraphics, St. Paul, MN). Maximal heart rate was measured by using a chest heart rate monitor (Polar Electro, Woodbury, NY).

Subjects were randomized to vitamin C or placebo groups. During the 7-day period before the race, subjects ingested three 500-mg tablets of vitamin $\mathrm{C}$ or placebo each day (one at each meal), and these tablets were administered in a doubleblinded fashion (and verified with post-study surveys). Subjects avoided food or beverages containing calories or caffeine other than the carbohydrate beverage supplied by the research team for $6 \mathrm{~h}$ before race start.

On race day, 29 ultramarathon runners reported to the start area at 4:30-5:00 AM. After subjects were allowed to sit for 10-15 min, blood samples were collected. Body mass was measured, and a chest heart rate monitor was attached to each runner. Runners received carbohydrate beverages with or without vitamin $\mathrm{C}$ in a double-blinded fashion by using a color code. The carbohydrate-vitamin $\mathrm{C}$ beverage contained vitamin $\mathrm{C}$ at a concentration of $150 \mathrm{mg} / \mathrm{l}$. Carbohydrate beverages, with or without vitamin C, were supplied by the Gatorade Sports Science Institute (Barrington, IL) as in earlier studies (19-23). Each runner ingested $750 \mathrm{ml}$ of beverage $\sim 30 \mathrm{~min}$ before the start of the race (5:30 AM) and one 500-mg vitamin C or placebo tablet. During the race, runners drank $\sim 1,000 \mathrm{ml}$ of beverage each hour (60 g carbohydrate/h). Research assistants were positioned every $5 \mathrm{~km}$ (3 aid stations on the $16-\mathrm{km}$ loop) to deliver color-coded beverage bottles that contained $500 \mathrm{ml}$ of fluid (with or without vitamin C). Runners ingested the fluid from two bottles per hour, and also ate two to three carbohydrate gel packs per hour (each containing $25 \mathrm{~g}$ ). Runners agreed to avoid all other beverages and food before and during the race. Research assistants also recorded heart rates and ratings of perceived exertion (RPE; $6-20$ scale) from each runner every $5 \mathrm{~km}$.

After subjects ran $32 \mathrm{~km}$, and then again after they crossed the $80-\mathrm{km}$-race finish line, subjects had blood and saliva samples collected in the seated position within 5 min (about $1 \mathrm{~min}$ to walk the subject to the sample-collection area and get them seated, and then the blood sample was immediately obtained during a 4-min timed saliva collection). Because of extreme environmental conditions (see RESULTS), some runners were unable to complete the race due to fatigue or the 12-h limit (imposed by the research team), and blood and saliva samples were collected from these runners as long as they had run $50 \mathrm{~km}$ or more. Body mass was also measured at $32 \mathrm{~km}$ and postrace. A postrace questionnaire verified compliance to all aspects of the research design by each runner.

Blood cell counts, hormones, glucose, and uric acid. Blood samples were drawn from an antecubital vein with subjects in the seated position. Routine complete blood counts and comprehensive diagnostic chemistries were performed by a clinical hematology laboratory (Lab Corp, Burlington, NC) and provided leukocyte subset counts, hemoglobin, hematocrit, and uric acid. Other blood samples were centrifuged in sodium heparin tubes, and plasma was aliquoted and then stored at $-80^{\circ} \mathrm{C}$. Plasma cortisol was assayed by using the competitive solid-phase ${ }^{125}$ I RIA technique (Diagnostic Products, Los Angeles, CA). RIA kits were also used to determine plasma concentrations of insulin and growth hormone according to manufacturer's instructions (Diagnostic Products). Plasma was analyzed spectrophotometrically for glucose. Plasma volume changes were estimated by using the method of Dill and Costill (8).

Oxidative measurements. Blood samples were immediately centrifuged at $4^{\circ} \mathrm{C}$ for $10 \mathrm{~min}$. Plasma was aliquoted into cryotubes and snap frozen in liquid nitrogen. Samples were stored at $-80^{\circ} \mathrm{C}$ until analysis. $\mathrm{F}_{2}$-isoprostane was analyzed by gas chromatography mass spectrometry (17). Lipid hydroperoxides $(\mathrm{ROOH})$ were analyzed by using a spectrophotometric kit provided by Caymen Chemicals (catalog no. 705002) (Ann Arbor, MI). The interassay coefficient of variation was $<5 \%$, and intra-assay coefficient of variation was $<10 \%$.

Lymphocyte subsets. The proportions of T cells $\left(\mathrm{CD}^{+}\right), \mathrm{B}$ cells $\left(\mathrm{CD} 19^{+}\right)$, and natural killer cells $\left(\mathrm{CD} 3^{-} \mathrm{CD} 16^{+} \mathrm{CD} 56^{+}\right)$ were determined in whole blood preparations, and absolute numbers were calculated by using complete blood count data to allow group comparisons of lymphocyte subset concentrations. Lymphocyte phenotyping was accomplished by twocolor fluorescent labeling of cell surface antigens with mouse anti-human monoclonal antibodies conjugated to FITC and phycoerythrin (PE) by using TriTEST reagents (Becton Dickinson, San Jose, CA). For immunophenotyping, 50- $\mu$ l aliquots of heparinized whole blood from each sample were added to two $12 \times 75$-mm polystyrene test tubes. Twenty 
microliters of CD3/CD16 + CD56/CD45 (BD Immunocytometry Systems, catalog no. 340300) or CD3/CD19/CD45 (BD Immunocytometry Systems, catalog no. 340381) were added to individual tubes of the two tube panels, and the samples were gently vortexed. After a 15-min incubation in the dark at room temperature, the red blood cells were lysed by adding $450 \mu \mathrm{l}$ of $1 \times$ FACS lysing solution (BD Immunocytometry, catalog no. 349202). The tubes were gently vortexed and incubated in the dark at room temperature for $15 \mathrm{~min}$. Samples were kept at $4^{\circ} \mathrm{C}$ in the dark until analyzed by flow cytometry (FACSort, Becton Dickinson).

Cytokine measurements. Total plasma concentrations of interleukin (IL)-1 receptor antagonist (IL-1 $1_{\mathrm{RA}}$ ), IL-6, IL-8, and IL-10 were determined by using quantitative sandwich ELISA kits provided by R\&D Systems (Minneapolis, MN). All samples and provided standards were analyzed in duplicate. A high-sensitivity kit was used to analyze IL-6 in the prerace plasma samples. A standard curve was constructed by using standards provided in the kits, and the cytokine concentrations were determined from the standard curves by using linear regression analysis. The assays were a two-step "sandwich" enzyme immunoassay in which samples and standards were incubated in a 96-well microtiter plate coated with polyclonal antibodies for the test cytokine as the capture antibody. After the appropriate incubation time, the wells were washed, and a second detection antibody was either conjugated to alkaline phosphatase (IL-6 high sensitivity) or had horseradish peroxidase (IL-1RA, IL-6, IL-8, IL-10) added. The plates were incubated and washed, and the amount of bound enzyme-labeled detection antibody was measured by adding a chromogenic substrate. The plates were then read at the appropriate wavelength (450-570 nm for IL-1 $1_{\mathrm{RA}}$, IL-6, IL-8, and IL-10; 490-650 nm for IL-6 high sensitivity). The minimum detectable concentration of IL-1 $1_{\mathrm{RA}}$ was $<22 \mathrm{pg} / \mathrm{ml}$, IL-6 $<0.70 \mathrm{pg} / \mathrm{ml}$, IL-6 high sensitivity $<0.094 \mathrm{pg} / \mathrm{ml}$, IL$8<10 \mathrm{pg} / \mathrm{ml}$, and IL-10 $<3.9 \mathrm{pg} / \mathrm{ml}$.

Phytohemagglutinin-induced lymphocyte proliferation and cytokine production. The mitogenic response of lymphocytes was determined in whole blood culture by using phytohemagglutinin (PHA) at optimal and suboptimal doses previously determined by titration experiments. Heparinized venous blood was diluted 1:10 with complete media consisting of RPMI 1640 supplemented with 5\% heat-inactivated fetal bovine serum, penicillin, streptomycin, L-glutamine, $\beta$-mercaptoethanol, and $\mathrm{Mito}^{+}$serum extender (BD Labware, catalog no. 355006). PHA was prepared in RPMI 1640 media at a concentration of $1 \mathrm{mg} / \mathrm{ml}$ and then further diluted with complete media to the optimal and suboptimal working concentrations $(25 \mu \mathrm{g} / \mathrm{ml}$ and $3.13 \mu \mathrm{g} / \mathrm{ml}$, respectively). A $100-\mu \mathrm{l}$ aliquot of the diluted blood was dispensed into each of triplicate wells of a 96 -well flat-bottom microtiter plate. To each well, $100 \mu \mathrm{l}$ of the appropriate mitogen dose were added. Control wells received complete media instead of mitogen. After 72 -h incubation at $37^{\circ} \mathrm{C}$ and $5 \% \mathrm{CO}_{2}$, a $100-\mu \mathrm{l}$ aliquot of the supernatant was removed from each well and immediately frozen at $-20^{\circ} \mathrm{C}$ for cytokine analyses. The cells were then pulsed with $1 \mu \mathrm{Ci}$ of thymidine-(methyl- ${ }^{3} \mathrm{H}$ ) (New England Nuclear, Boston, MA) prepared with RPMI 1640. After pulsing, cells were incubated for an additional $4 \mathrm{~h}$ before harvesting. Radionucleotide incorporation was assessed by liquid scintillation counting with the results expressed as experimental minus control counts per minute. PHA-induced proliferation expressed on a "per T cell" basis was calculated by dividing the counts per minute data by the number of $\mathrm{T}$ cells in the assay wells. Concentrations of secreted interferon (IFN)- $\gamma$ and IL-2 were determined from the frozen cell supernatants by using quantitative sandwich ELISA kits provided by R\&D Systems. At the time of cytokine evaluation, the supernatants were diluted 10- to 35-fold due to the expected high concentration of cytokines in the samples (on the basis of proliferation data). This was necessary to bring the concentration within the interpolating range of the respective standard curve. The minimum detectable concentration for IFN- $\gamma$ was $<8 \mathrm{pg} / \mathrm{ml}$ and for IL-2 was $<7 \mathrm{pg} / \mathrm{ml}$.

Statistical analysis. Statistical significance was set at the $P<0.05$ level, and values were expressed as means $\pm \mathrm{SE}$. Vitamin $\mathrm{C}$ and placebo groups were compared for subject characteristics and race performance measures by using independent $t$-tests (Tables 1 and 2 ). Leukocyte subset counts, oxidative and cytokine measures, mitogen-stimulated lymphocyte proliferation and cytokine production, and hormone values were analyzed by using 2 (vitamin $\mathrm{C}$ and placebo groups) $\times 3$ (times of measurement) repeated-measures ANOVA. When Box's M suggested that the assumptions necessary for the univariate approach were not tenable, a multivariate approach to repeated-measures ANOVA was used. In the latter case, the Pillais trace statistic was used as the test statistic. If the group $\times$ time interaction $P$ value was $\leq 0.05$, the change from baseline for the $32-\mathrm{km}$ and postrace values was calculated and compared between groups by using Student's $t$-tests. For these two multiple comparisons across groups, a Bonferroni adjustment was made, with statistical significance set at $P<0.025$. Pearson product-moment correlations were used to test the relationship between postrace measurements.

\section{RESULTS}

Twenty-eight ultramarathoners fully complied with all protocol requirements (Table 1). This included 15 runners in the vitamin $\mathrm{C}$ group and 13 runners in the placebo group. Age, stature, body mass, running and racing experience, and cardiorespiratory fitness did not differ significantly between groups. The prerace diet measured from 7-day food records did not differ significantly between groups, with a mean energy intake of $11.2 \pm 0.2 \mathrm{MJ} /$ day, carbohydrate intake of $55.3 \pm 2.8 \%$ total energy, fat intake of $29.0 \pm 1.8 \%$ total energy, and vitamin $\mathrm{C}$ intake of $147 \pm 24 \mathrm{mg} /$ day.

Environmental conditions at the 6:00 AM race start were $18^{\circ} \mathrm{C}$ and $90 \%$ relative humidity $(\mathrm{RH})$, at $10: 00$ AM were $24^{\circ} \mathrm{C}$ and $60 \% \mathrm{RH}$, at $2: 00 \mathrm{PM}$ were $31^{\circ} \mathrm{C}$ and $40 \% \mathrm{RH}$, and at 6:00 $\mathrm{PM}$ were $30^{\circ} \mathrm{C}$ and $40 \% \mathrm{RH}$. Ultramarathon race performance measurements are

\section{Table 1. Subject characteristics}

\begin{tabular}{lccc}
\hline \hline \multicolumn{1}{c}{ Characteristic } & $\begin{array}{c}\text { Vitamin } \mathrm{C} \\
(n=15)\end{array}$ & $\begin{array}{c}\text { Placebo } \\
(n=13)\end{array}$ & $\begin{array}{c}P \\
\text { Value }\end{array}$ \\
\hline Age, yr & $49.9 \pm 3.5$ & $45.2 \pm 2.8$ & 0.312 \\
Stature, $\mathrm{m}$ & $1.73 \pm 0.02$ & $1.74 \pm 0.02$ & 0.642 \\
Body mass, kg & $76.8 \pm 2.4$ & $76.4 \pm 2.8$ & 0.912 \\
Running experience, yr & $14.3 \pm 2.3$ & $13.7 \pm 2.5$ & 0.852 \\
Training distance, $\mathrm{km} / \mathrm{wk}$ & $58.9 \pm 9.7$ & $70.3 \pm 5.6$ & 0.321 \\
Ultramarathons raced & $21.2 \pm 8.1$ & $20.3 \pm 6.6$ & 0.934 \\
$\mathrm{~V}_{2 m a x}, \mathrm{ml} \cdot \mathrm{kg}^{-1} \cdot \mathrm{min}^{-1}$ & $47.2 \pm 1.8$ & $48.4 \pm 2.3$ & 0.693 \\
$\mathrm{VE}_{\text {max }}, \mathrm{l} / \mathrm{min}$ & $134 \pm 6$ & $137 \pm 6$ & 0.689 \\
$\mathrm{HR}_{\text {max }}$, beats/min & $181 \pm 4$ & $183 \pm 4$ & 0.725 \\
$\mathrm{RER}_{\text {max }}$ & $1.15 \pm 0.02$ & $1.16 \pm 0.02$ & 0.841 \\
\hline
\end{tabular}

Values are means $\pm \mathrm{SE}$. $\dot{\mathrm{V}}_{2 \max }$, maximal oxygen consumption; $\dot{\mathrm{V}} \mathrm{E}_{\max }$, maximal exercise ventilation; $\mathrm{HR}_{\max }$, maximum heart rate; $\mathrm{RER}_{\max }$, maximum respiratory exchange ratio. 
Table 2. Race performance measures

\begin{tabular}{lccc}
\hline \hline \multicolumn{1}{c}{ Parameter } & $\begin{array}{c}\text { Vitamin C } \\
(n=15)\end{array}$ & $\begin{array}{c}\text { Placebo } \\
(n=13)\end{array}$ & $\begin{array}{c}P \\
\text { Value }\end{array}$ \\
\hline Average HR, beats/min & $135 \pm 4$ & $136 \pm 5$ & 0.885 \\
Average \%HR $\max$ & $75.7 \pm 1.9$ & $75.2 \pm 2.1$ & 0.852 \\
End RPE & $14.3 \pm 1.2$ & $15.0 \pm 1.8$ & 0.677 \\
Race distance, km & $68.7 \pm 3.3$ & $68.7 \pm 3.5$ & 0.993 \\
Race time, $\mathrm{h}$ & $9.85 \pm 0.36$ & $9.68 \pm 0.66$ & 0.820 \\
Fluid intake, 1/hr & $1.04 \pm 0.08$ & $0.85 \pm 0.06$ & 0.067 \\
Body mass loss, kg & $-1.88 \pm 0.37$ & $-1.79 \pm 0.24$ & 0.850 \\
Plasma volume change, \% & $-4.02 \pm 0.48$ & $-2.74 \pm 0.55$ & 0.088 \\
\hline
\end{tabular}

Values are means \pm SE. HR, heart rate; $\mathrm{RPE}$, rating of perceived exertion.

summarized in Table 2. Subjects in both groups maintained an intensity of $\sim 75 \%$ of maximum heart rate throughout the ultramarathon race and ran a mean of $69 \mathrm{~km}$ (range of $48-80 \mathrm{~km}$ ) in $9.8 \mathrm{~h}$ (range of 5-12 h). Ratings of perceived exertion averaged 11 ("fairly light") during the first $15 \mathrm{~km}$ and rose to just over 15 ("hard") by the end of the race. Fluid intake was close to the 1 liter/h goal throughout the race (mean intake of $57 \mathrm{~g}$ carbohydrate/h), resulting in modest changes in body mass and plasma volume. Runners also averaged $2.3 \pm 0.2$ gel packs or $58 \mathrm{~g}$ carbohydrate/h .

Plasma ascorbic acid was markedly higher in the vitamin $\mathrm{C}$ compared with placebo group and rose more strongly in the vitamin $\mathrm{C}$ group during the race (Fig. 1). Serum uric acid (Table 3) was negatively correlated with plasma ascorbic acid postrace $(r=-0.47, P=$ 0.012 ), and uric acid was significantly lower in the vitamin $\mathrm{C}$ compared with placebo group (group effect across time points, $P=0.002$ ). No significant group or interaction effects were measured for lipid hydroperoxide and $\mathrm{F}_{2}$-isoprostane, but both oxidative measures rose significantly during the ultramarathon race ( $\mathrm{Ta}-$ ble 3). Postrace lipid hydroperoxide and $\mathrm{F}_{2}$-isoprostane

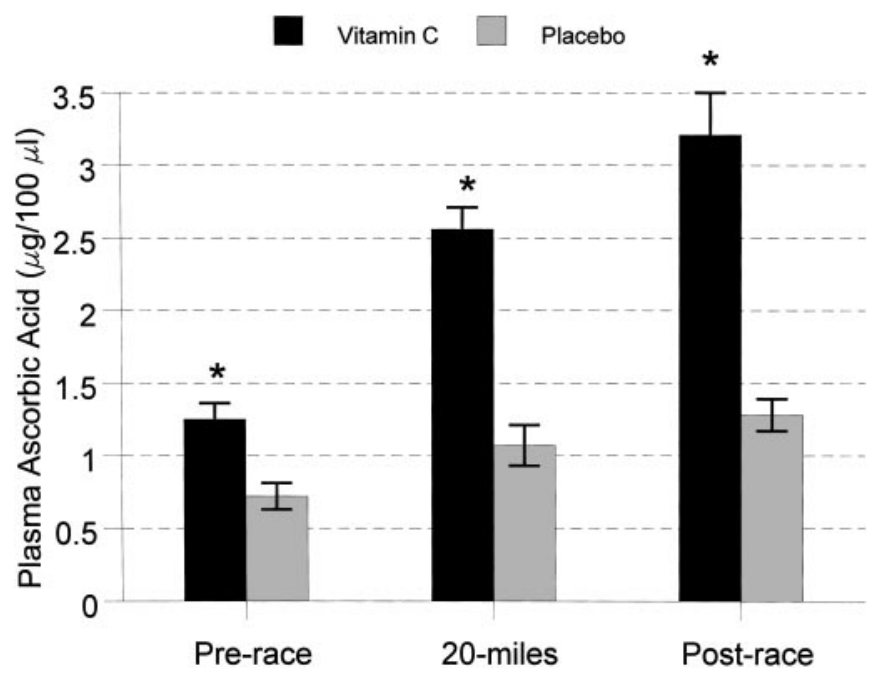

Fig. 1. Serum vitamin C concentrations before, during, and after competing in an ultramarathon race in placebo and vitamin $\mathrm{C}$ groups. Data are presented as means \pm SE. * Significantly different from placebo group $(P<0.05)$. Group, interaction, and time effects, all $P<0.001$.
Table 3. Oxidative measures, plasma glucose, and hormones

\begin{tabular}{|c|c|c|c|c|}
\hline Parameter & Prerace & $32 \mathrm{~km}$ & Postrace & $\begin{array}{c}\text { Effect: } \\
\text { Group } \\
\text { Interaction } \\
\text { Time }\end{array}$ \\
\hline $\begin{array}{l}\text { Lipid hydroperoxide, } \\
\mu \mathrm{M}\end{array}$ & & & & 0.921 \\
\hline Vitamin C & $31.3 \pm 2.1$ & $32.1 \pm 2.3$ & $39.8 \pm 4.4$ & 0.079 \\
\hline Placebo & $36.3 \pm 0.7$ & $27.0 \pm 3.1$ & $39.2 \pm 3.6$ & 0.027 \\
\hline $\begin{array}{l}\mathrm{F}_{2} \text {-isoprostane, } \\
\mathrm{pg} / \mathrm{ml}\end{array}$ & & & & 0.051 \\
\hline Vitamin C & $60.4 \pm 8.2$ & $64.5 \pm 7.0$ & $75.1 \pm 5.6$ & 0.864 \\
\hline Placebo & $44.8 \pm 2.8$ & $53.7 \pm 4.0$ & $62.6 \pm 2.8$ & 0.003 \\
\hline $\begin{array}{l}\text { Uric acid, } \\
\mathrm{mg} / \mathrm{dl}\end{array}$ & & & & 0.002 \\
\hline Vitamin C & $4.05 \pm 0.34$ & $3.51 \pm 0.21$ & $4.07 \pm 0.29$ & 0.210 \\
\hline Placebo & $4.95 \pm 0.31$ & $5.02 \pm 0.28$ & $5.49 \pm 0.32$ & 0.001 \\
\hline $\begin{array}{c}\text { Serum glucose, } \\
\mathrm{mmol} / \mathrm{l}\end{array}$ & & & & 0.087 \\
\hline Vitamin C & $6.65 \pm 0.16$ & $7.94 \pm 0.21$ & $7.07 \pm 0.46$ & 0.470 \\
\hline Placebo & $8.14 \pm 0.78$ & $8.95 \pm 0.54$ & $7.67 \pm 0.55$ & $<0.001$ \\
\hline $\begin{array}{l}\text { Serum insulin, } \\
\mathrm{pmol} / /\end{array}$ & & & & 0.064 \\
\hline Vitamin C & $35.8 \pm 2.8$ & $74.8 \pm 13.3$ & $39.6 \pm 5.4$ & 0.713 \\
\hline Placebo & $59.3 \pm 10.9$ & $96.6 \pm 16.8$ & $53.0 \pm 6.9$ & 0.002 \\
\hline $\begin{array}{l}\text { Serum cortisol, } \\
\mathrm{nmol} / /\end{array}$ & & & & 0.673 \\
\hline Vitamin C & $583 \pm 28$ & $664 \pm 68$ & $1293 \pm 142$ & 0.673 \\
\hline Placebo & $678 \pm 40$ & $750 \pm 58$ & $1014 \pm 101$ & $<0.001$ \\
\hline
\end{tabular}

Values are means $\pm \mathrm{SE}$.

were positively correlated $(r=0.44, P=0.019) . \mathrm{F}_{2^{-}}$ isoprostane tended to be higher in the vitamin $\mathrm{C}$ compared with placebo group across all time points (group effect, $P=0.051$ ). No significant interaction effects were measured for serum glucose and insulin, which tended to rise at $32 \mathrm{~km}$ and then fall closer to prerace levels by race end. Serum cortisol rose strongly in both groups during the race, with a slightly greater increase measured in the vitamin $\mathrm{C}$ group.

No significant group or interaction effects were measured for immune cell counts (Table 4). Neutrophil and monocyte counts rose in both groups during the race, with a decrease measured for T cell and natural killer lymphocyte counts. Plasma cytokine concentrations rose strongly during the race, but no significant group or interaction effects were measured (Table 5). Mitogen-stimulated lymphocyte proliferation (PHA, $25 \mu \mathrm{g} /$ ml; Fig. 2) and IL-2 and IFN- $\gamma$ production (Table 5) decreased strongly during the race $(68,63$, and $72 \%$, respectively), but no significant group or interaction effects were measured. Figure $2 B$ shows that mitogenstimulated lymphocyte proliferation adjusted for changes in T-cell counts was still $57 \%$ below prerace levels after the race (all subjects combined). Similar findings were found for mitogen-stimulated lymphocyte proliferation at a PHA concentration of $3 \mu \mathrm{g} / \mathrm{ml}$ (data not shown).

Postrace serum cortisol was positively correlated to serum vitamin C ( $r=0.50, P=0.006)$ and IL-10 $(r=$ $0.65, P<0.001$ ), postrace $\mathrm{F}_{2}$-isoprostane was positively correlated to IL-10 ( $r=0.42, P=0.026)$, but no other significant correlations were found between se- 
Table 4. Immune cell counts

\begin{tabular}{|c|c|c|c|c|}
\hline Cell count, $10^{9} / 1$ & Prerace & $32 \mathrm{~km}$ & Postrace & $\begin{array}{c}\text { Effect: } \\
\text { Group } \\
\text { Interaction } \\
\text { Time }\end{array}$ \\
\hline Neutrophils & & & & 0.942 \\
\hline Vitamin C & $2.84 \pm 0.21$ & $5.97 \pm 0.44$ & $11.43 \pm 0.85$ & 0.958 \\
\hline Placebo & $2.95 \pm 0.22$ & $5.92=$ & 11.25 & $<0.001$ \\
\hline Monocytes & & & & 0.476 \\
\hline Vitamin C & $0.32 \pm 0.02$ & $0.28 \pm 0.04$ & $0.65 \pm 0.07$ & 0.597 \\
\hline Placebo & $0.32 \pm 0.03$ & $0.28 \pm 0.05$ & $0.79 \pm 0.14$ & $<0.001$ \\
\hline Total lymphocytes & & & & 0.967 \\
\hline Vitamin $\mathrm{C}$ & $2.02 \pm 0.14$ & $1.43 \pm 0.06$ & $1.57 \pm 0.15$ & 0.942 \\
\hline Placebo & $2.03 \pm 0.15$ & $1.46 \pm 0.15$ & $1.55 \pm 0.13$ & $<0.001$ \\
\hline Iymphocytes & & & & 0.962 \\
\hline Vitamin C & $1.44 \pm 0.10$ & $1.02 \pm 0.06$ & $1.03 \pm 0.11$ & 0.879 \\
\hline Placebo & $1.41 \pm 0.10$ & $1.05 \pm 0.11$ & $1.04 \pm 0.08$ & $<0.001$ \\
\hline B lymphocytes & & & & 0.466 \\
\hline Vitamin C & $.19 \pm 0.02$ & $0.15 \pm 0.01$ & $0.19 \pm 0.02$ & 0.929 \\
\hline Placebo & $0.21 \pm 0.03$ & $0.16 \pm 0.02$ & $0.22 \pm 0.03$ & $<0.001$ \\
\hline $\begin{array}{l}\text { Natural killer } \\
\text { lymphocytes }\end{array}$ & & & & 0.821 \\
\hline Vitamin C & $0.35 \pm 0.07$ & $0.23 \pm 0.04$ & $0.31 \pm 0.05$ & 0.655 \\
\hline Placebo & $0.36 \pm 0.04$ & $0.21 \pm 0.02$ & $0.27 \pm 0.04$ & $<0.001$ \\
\hline
\end{tabular}

Values are means $\pm \mathrm{SE}$.

rum vitamin $\mathrm{C}$, oxidative, hormonal, and immune measures.

\section{DISCUSSION}

Runners in this study were able to maintain an intensity of $\sim 75 \%$ maximal heart rate for nearly $10 \mathrm{~h}$ during an unexpectedly hot spring day. Vitamin C compared with placebo supplementation $(1,500 \mathrm{mg} /$ day for 7 days before and the day of the ultramarathon race) was associated with elevated plasma vitamin $\mathrm{C}$

Table 5. Plasma cytokines and mitogen-stimulated cytokine production

\begin{tabular}{|c|c|c|c|c|}
\hline $\begin{array}{c}\text { Cytokine, } \\
\text { pg/ml }\end{array}$ & Prerace & $32 \mathrm{~km}$ & Postrace & $\begin{array}{c}\text { Effect: } \\
\text { Group } \\
\text { Interaction } \\
\text { Time }\end{array}$ \\
\hline IL-6 & & & & 0.304 \\
\hline Vitamin $\mathrm{C}$ & $1.3 \pm 0.2$ & $10.8 \pm 2.8$ & $46.5 \pm 5.1$ & 0.202 \\
\hline Placebo & $1.3 \pm 0.2$ & $11.0 \pm 2.0$ & $36.1 \pm 6.3$ & $<0.001$ \\
\hline IL-1 $1_{\mathrm{RA}}$ & & & & 0.390 \\
\hline Vitamin C & $170 \pm 12$ & $388 \pm 33$ & $958 \pm 106$ & 0.777 \\
\hline Placebo & $204 \pm 25$ & $410 \pm 50$ & $1,176 \pm 289$ & $<0.001$ \\
\hline IL-10 & & & & 0.976 \\
\hline Vitamin C & $3.0 \pm 0.4$ & $4.4 \pm 1.6$ & $17.1 \pm 5.3$ & 0.192 \\
\hline Placebo & $3.1 \pm 0.4$ & $7.9 \pm 3.0$ & $13.8 \pm 3.4$ & 0.003 \\
\hline IL-8 & & & & 0.803 \\
\hline Vitamin C & $7.9 \pm 1.3$ & $16.4 \pm 1.6$ & $28.5 \pm 3.5$ & 0.892 \\
\hline Placebo & $8.7 \pm 2.3$ & $18.0 \pm 1.8$ & $28.1 \pm 3.9$ & $<0.001$ \\
\hline IL-2, PHA 25 & & & & \\
\hline$\mu \mathrm{g} / \mathrm{ml}$ & & & & 0.094 \\
\hline Vitamin C & $140.3 \pm 31.8$ & $95.9 \pm 18.7$ & $46.1 \pm 12.8$ & 0.188 \\
\hline Placebo & $79.5 \pm 22.2$ & $49.0 \pm 7.1$ & $36.6 \pm 5.0$ & 0.002 \\
\hline IFN- $\gamma$, PHA & & & & \\
\hline $25 \mu \mathrm{g} / \mathrm{ml}$ & & & & 0.240 \\
\hline Vitamin C & $2,414 \pm 266$ & $1,269 \pm 207$ & $638 \pm 167$ & 0.419 \\
\hline Placebo & $1,936 \pm 260$ & $948 \pm 205$ & $570 \pm 119$ & $<0.001$ \\
\hline
\end{tabular}

Values are means \pm SE. IL, interleukin; IL-1 $1_{\mathrm{RA}}$, IL-1-receptor antagonist; PHA, phytohemagglutinin; IFN, interferon.

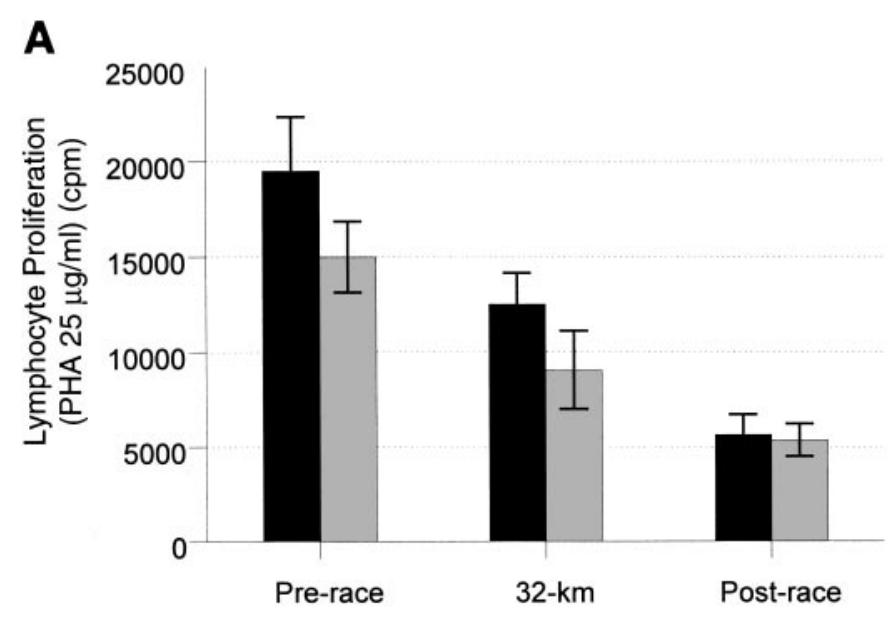

B

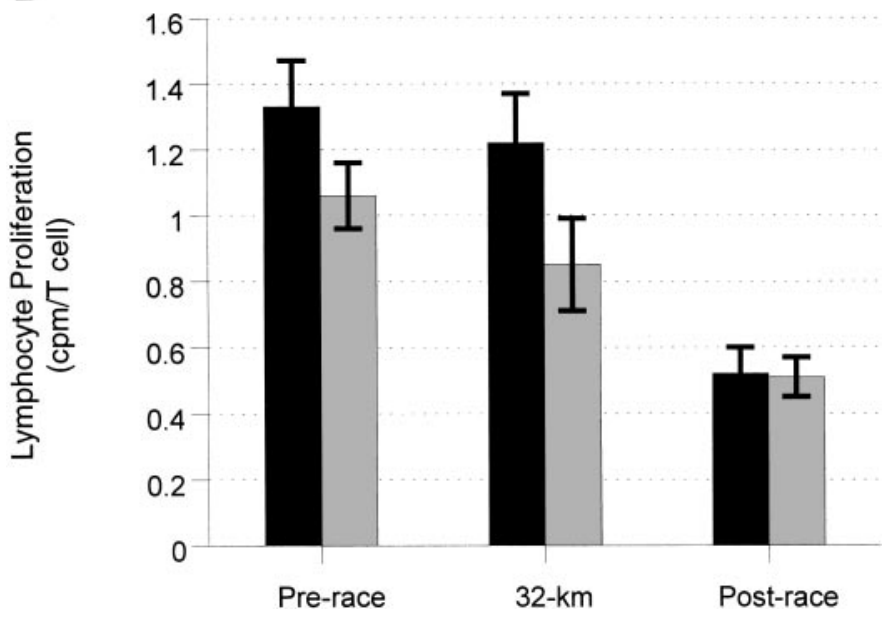

Fig. 2. A: phytohemagglutinin (PHA; $25 \mu \mathrm{g} / \mathrm{ml}$ )-stimulated lymphocyte proliferation before (prerace), during $(32 \mathrm{~km}$ ), and after (postrace) competing in an ultramarathon race in placebo (gray bars) and vitamin C (black bars) groups. Group effect, $P=0.220$; interaction, $P=0.243$; time, $P=<0.001$. $B$ : PHA $(25 \mu \mathrm{g} / \mathrm{ml})$-stimulated lymphocyte proliferation adjusted for changes in T-cell counts, prerace, at 32 $\mathrm{km}$, and postrace in placebo (gray bars) and vitamin C (black bars) groups. Data are means \pm SE. cpm, Counts per minute. Group effect, $P=0.133$; interaction, $P=0.068$; time, $P=<0.001$.

and diminished uric acid levels but had no consistent influence on postrace oxidative or immune alterations. This is the first study to test the influence of vitamin $\mathrm{C}$ supplementation on measures of both oxidative and immune stress after a competitive race. Except for a positive correlation between $\mathrm{F}_{2}$-isoprostane and plasma IL-10, no other significant correlations were found between postrace plasma vitamin $\mathrm{C}$, oxidative, and immune measures.

These data are in agreement with three other studies that also reported no differences in immune changes between vitamin $\mathrm{C}$ and placebo groups after heavy exertion $(14,21,28)$. In a previous study in our laboratory (21), 12 marathoners ran for $2.5 \mathrm{~h}$ on treadmills under vitamin $\mathrm{C}$ or placebo conditions $(1,000$ $\mathrm{mg} /$ day for 8 days), and no differences were measured in hormonal and immune measures (including natural killer cell activity, mitogen-stimulated lymphocyte pro- 
liferation, granulocyte/monocyte phagocytosis and oxidative burst activity, leukocyte subsets, and IL-6). Krause et al. (14) reported no effects of vitamin C supplementation (2,000 $\mathrm{mg}$ for $1 \mathrm{wk})$ on neutrophil phagocytosis and bactericidal ability in six men after a competitive biathlon (16-km uphill cycling and $2-\mathrm{km}$ uphill running). However, that study did not include a placebo supplement, and subjects were not randomized to treatment conditions. In another investigation (28), 20 male runners took $500 \mathrm{mg}$ of vitamin $\mathrm{C}$ and $400 \mathrm{mg}$ of vitamin $\mathrm{E}$ or placebo for 14 days before and 7 days after running downhill for $90 \mathrm{~min}$ on treadmills. Despite a substantial elevation in plasma levels of vitamin $\mathrm{C}$ and $\mathrm{E}$, no groups differences were measured for cytokines and lymphocyte subsets, and the authors concluded that exercise-induced inflammatory responses are not induced by free oxygen radicals. However, in that study, no measures of oxidative stress were reported.

In a study of 29 ultramarathon runners competing in the Comrades $90-\mathrm{km}$ race, vitamin $\mathrm{C}$ compared with placebo supplementation did attenuate postrace increases in cortisol, epinephrine, leukocyte subset counts, and cytokines $(24,26)$. These results differ markedly from the present study, and several explanations are possible. In the Comrades study, subjects were not randomized to treatment groups, and carbohydrate intake during the race was ad libitum and retrospectively estimated, in contrast to methods followed in the present study $(24,26)$. Carbohydrate compared with placebo beverage ingestion has a marked effect on postexercise changes in stress hormones and immunity, in particular, those related to inflammation, including cortisol, pro- and anti-inflammatory cytokines (IL-6, IL-10, IL-1 $1_{\mathrm{RA}}$ ), neutrophil and monocyte cell counts, and granulocyte/monocyte phagocytosis and oxidative burst activity (19, 20, 22, 23). Carbohydrates have little influence on salivary IgA and measures related to adaptive immunity, including mitogen-stimulated lymphocyte proliferation and cytokine production by isolated cells in vitro (20). In the present study, all ultramarathon runners used carbohydrate beverages and gels, ingesting an average of $115 \mathrm{~g} / \mathrm{h}$, thus keeping serum glucose concentrations at a high level and preventing the typical exercise-induced decrease in insulin. This high intake of carbohydrates was more than likely responsible for the modest perturbations in leukocyte subset cell counts and antiinflammatory cytokines (i.e., modest compared with changes in these immune measurements we have measured in the placebo state after a competitive marathon race or $2.5 \mathrm{~h}$ of running or cycling in the lab) $(22,23)$. In contrast, the decrease in mitogen-stimulated lymphocyte proliferation and cytokine production for all subjects combined was greater than in all of our previous laboratory and field studies.

$\mathrm{ROOH}$ are formed from the oxidative conversion of polyunsaturated fatty acids and are one of the major initial reactants of lipid peroxidation. If not terminated by antioxidants, the chain of peroxidation events can become self-perpetuating, resulting in steadily in- creased levels of ROOH. ROOH are toxic and capable of damaging most body cells (18). In addition to the nutrient antioxidants vitamins $\mathrm{E}$ and $\mathrm{C}$, catalase and glutathione peroxidase are endogenous antioxidant enzymes that neutralize ROOH. Typically, unless glutathione peroxidase or catalase are overwhelmed or inhibited, $\mathrm{ROOH}$ will not accumulate in plasma or other tissues. Studies that have found increased $\mathrm{ROOH}$ usually required subjects to exercise to exhaustion $(1,36)$. In the present study, $\mathrm{ROOH}$ were slightly elevated in the runners postrace, implying that antioxidant activities were sufficient to prevent a large increase in $\mathrm{ROOH}(7,25)$.

Unlike $\mathrm{ROOH}, \mathrm{F}_{2}$-isoprostanes are stable prostaglandin-like compounds produced by free radical catalyzed peroxidation of arachidonic acid, independent of the cyclooxygenase pathway. Another interesting aspect is that $\mathrm{F}_{2}$-isoprostanes are formed esterified to phospholipids in vivo and possess potent biological activity such as vasoconstriction of smooth muscle and stimulation of platelet aggregation $(10,17)$. As such, $\mathrm{F}_{2}$-isoprostanes may serve as mediators of oxidant stress (10). $\mathrm{F}_{2}$-isoprostane values were significantly increased during running in both the vitamin $\mathrm{C}$ and placebo groups. This indicates that the ultramarathon run induced oxidative stress. We believe this is the first study to report plasma $\mathrm{F}_{2}$-isoprostanes in exercising humans.

$\mathrm{F}_{2}$-isoprostanes are known to increase intracellular calcium levels in cells expressing thromboxane receptors $(15,17)$. Additionally, many types of immune cells are known to be activated by intracellular calcium signaling $(10,13,16)$. Although we found no statistical correlation between immune variables and oxidative stress, with the exception of a weak association between IL-10 and $\mathrm{F}_{2}$-isoprostane values, the possibility exists that $\mathrm{F}_{2}$-isoprostanes may influence or modulate immune function.

There is limited evidence that exercise-induced oxidative stress is related to alterations in immune function. Oxidants may directly and indirectly induce cell adhesion, thereby influencing the inflammatory process (33). In one study of 19 men engaging in exhaustive exercise, significant correlations were reported between oxidative stress measures and mitogen-induced lymphocyte proliferation and acute phase response (35). Strenuous physical exercise of limb muscles typically results in muscle soreness and injury, especially during intensive, prolonged exercise, such as ultramarathon race competition. During heavy exertion, the unusual metabolic demands cause an increase in ROS generation, in part due to the influx of neutrophils into muscle tissues, which are a major source of extracellular ROS. ROS causes a wide spectrum of cellular damage and may mediate leukocyte apoptosis (3).

There is some evidence that vitamin $\mathrm{C}$ protects cells from oxidative damage, thereby reducing inflammation and cytokine production $(4,6,32)$. Neutrophil ROS have a damaging effect on the neutrophils themselves, and, for protection, these cells acquire a high level of ascorbic acid (39). However, the relationship between 
vitamin C supplementation, muscle soreness, and oxidative stress is not clear at this time. In a study of highly trained runners (31), $1 \mathrm{~g}$ of vitamin $\mathrm{C}$ ingested immediately before a 4 -h race inhibited oxidation of low-density lipoprotein. Thoroughbred racehorses treated intravenously with $5,000 \mathrm{mg}$ of vitamin $\mathrm{C}$ before a $1,000-\mathrm{m}$ race at maximal velocity experienced less oxidative stress but similar muscle damage to untreated horses (38). In contrast, sled dogs given vitamin $\mathrm{C}, \mathrm{E}$, and beta carotene supplements or placebos during 3 days of intensive exercise experienced similar postexercise changes in measures of oxidative stress and muscle damage (29). Marathon runners given vitamin $\mathrm{E}$ and $\mathrm{C}$ supplements or placebos for 4.5 wk before a competitive marathon race experienced lower creatine kinase but similar postrace changes in lipid peroxidation (30). In another study, 1,000 $\mathrm{mg}$ of vitamin $\mathrm{C}$ compared with placebo ingestion $2 \mathrm{~h}$ before 90 min of intermittent shuttle-running did not influence markers of both muscle damage and lipid peroxidation (34). Thus vitamin C supplementation before prolonged and intensive exercise does not have a consistent effect on blood measures of oxidative stress and muscle damage, and any linkage to immune perturbations remains speculative and more than likely improbable.

In summary, our data indicate that vitamin C supplementation does not serve as a countermeasure to postrace oxidative and immune changes in carbohydrate-fed ultramarathon runners. Statistical correlations suggest that oxidative stress had little influence on the immune changes that take place during or after a competitive ultramarathon race.

This work was funded by the Gatorade Sports Science Institute and National Institutes of Health Grants (to J. D. Morrow) DK48831, GM-15431, CA-77839, and DK-26657. J. D. Morrow is the recipient of a Burroughs Wellcome Fund Clinical Scientist Award in Translational Research.

\section{REFERENCES}

1. Allesio H, Hagerman AE, Fulkerson BK, Ambrose J, Rice RE, and Wiley RL. Generation of reactive oxygen species after exhaustive aerobic and isometric exercise. Med Sci Sports Exerc 32: 1576-1581, 2000.

2. Ashton T, Young IS, Peters JR, Jones E, Jackson SK, Davies B, and Rowlands CC. Electron spin resonance spectroscopy, exercise, and oxidative stress: an ascorbic acid intervention study. J Appl Physiol 87: 2032-2036, 1999.

3. Azenabor AA and Hoffman-Goetz L. Intrathymic and intrasplenic oxidative stress mediates thymocyte and splenocyte damage in acutely exercised mice. J Appl Physiol 86: 1823-1827, 1999.

4. Bijur GN, Briggs B, Hitchcock CL, and Williams MV. Ascorbic acid-dehydroascorbate induces cell cycle arrest at G2/M DNA damage checkpoint during oxidative stress. Environ Mol Mutagen 33: 144-152, 1999.

5. Campbell JD, Cole M, Bunditrutavorn B, and Vella AT. Ascorbic acid is a potent inhibitor of various forms of $\mathrm{T}$ cell apoptosis. Cell Immunol 194: 1-5, 1999.

6. Chen CY, Huang YL, and Lin TH. Association between oxidative stress and cytokine production in nickel-treated rats. Arch Biochem Biophys 356: 127-132, 1998.

7. Dekkers JC, van Doornen L, and Kemper H. The role of antioxidant vitamins and enzymes in the prevention of exerciseinduced muscle damage. Sports Med 21: 213-238, 1996.
8. Dill DB and Costill DL. Calculation of percentage changes in volumes of blood, plasma, and red cells in dehydration. J Appl Physiol 37: 247-248, 1974.

9. Dwenger A, Funck M, Lueken B, Schweitzer G, and Lehmann U. Effect of ascorbic acid on neutrophil functions and hypoxanthine/xanthine oxidase-generated, oxygen-derived radicals. Eur J Clin Chem Clin Biochem 30: 187-191, 1992.

10. Habib A, Fitzgerald GA, and Maclouf J. Phosphorylation of the thromboxane receptor $\alpha$, the predominant isoform expressed in human platelets. J Biol Chem 274: 2645-2651, 1999.

11. Hughes DA. Effects of dietary antioxidants on the immune function of middle-aged adults. Proc Nutr Soc 58: 79-84, 1999.

12. Jacob RA, Kelley DS, and Pianalto FS. Immunocompetence and oxidant defense during ascorbate depletion of healthy men. Am J Clin Nutr 54, Suppl: 1302S-1309S, 1991.

13. Kozawa O, Suzuki A, Tokuda H, and Uematsu T. Prostaglandin $\mathrm{F}_{2 \alpha}$ stimulates interleukin-6 synthesis via activation of PKC in osteoblast-like cells. Am J Physiol Endocrinol Metab 272: E208-E211, 1997.

14. Krause R, Patruta S, Daxbock F, Fladerer P, Biegelmayer $\mathbf{C}$, and Wenisch C. Effect of vitamin C on neutrophil function after high-intensity exercise. Eur $J$ Clin Invest 31: 258-263, 2001.

15. Mohler ER, Franklin MT, and Adam LP. Intracellular signaling by 8-epi-prostaglandin $\mathrm{F}_{2 \alpha}$ is mediated by thromboxane $\mathrm{A}_{2} /$ prostaglandin endoperoxide receptors in porcine carotid arteries. Biochem Biophys Res Commun 225: 915-923, 1996.

16. Mooren F, Lechtermann A, Fromme A, Thorwesten L, and Volker K. Alterations in intracellular calcium signaling of lymphocytes after exhaustive exercise. Med Sci Sports Exerc 33: 242-248, 2001.

17. Morrow JD and Roberts LJ. The isoprostanes: unique bioactive products of lipid peroxidation. Prog Lipid Res 36: 1-21, 1997.

18. Mylonas C and Kouretas D. Lipid peroxidation and tissue damage. In Vivo 13: 295-310, 1999.

19. Nehlsen-Cannarella SL, Fagoaga OR, Nieman DC, Henson DA, Butterworth DE, Bailey E, Warren BJ, and Davis JM. Carbohydrate and the cytokine response to 2.5 hours of running. J Appl Physiol 82: 1662-1667, 1997.

20. Nieman DC. Carbohydrates and the immune response to prolonged exertion. In: Nutrition and Exercise Immunology, edited by Nieman DC and Pedersen BK. Boca Raton, FL: CRC Press, 2000, p. 25-42.

21. Nieman DC, Henson DA, Butterworth DE, Warren BJ, Davis JM, Fagoaga OR, and Nehlsen-Cannarella SL. Vitamin $\mathrm{C}$ supplementation does not alter the immune response to 25 hours of running. Int $J$ Sport Nutr 7: 173-184, 1997.

22. Nieman DC, Henson DA, Smith LL, Utter AC, Vinci DM, Davis JM, Kaminsky DE, and Shute M. Cytokine changes after a marathon race. J Appl Physiol 91: 109-114, 2001.

23. Nieman DC, Nehlsen-Cannarella SL, Fagoaga OR, Henson DA, Utter A, Davis JM, Williams F, and Butterworth DE. Influence of mode and carbohydrate on the cytokine response to heavy exertion. Med Sci Sports Exerc 30: 671-678, 1998.

24. Nieman DC, Peters EM, Henson DA, Nevines EI, and Thompson MM. Influence of vitamin $\mathrm{C}$ supplementation on cytokine changes following an ultramarathon. J Interferon $C y$ tokine Res 20: 1029-1035, 2000.

25. Packer L. Oxidants, antioxidant nutrients and the athlete. J Sports Sci 15: 353-363, 1997.

26. Peters EM, Anderson R, Nieman DC, Fickl H, and Jogessar V. Vitamin C supplementation attenuates the increases in circulating cortisol, epinephrine and anti-inflammatory polypeptides following ultramarathon running. Int J Sports Med 22: 537-543, 2002.

27. Peters EM, Anderson R, and Theron AJ. Attenuation of the increase in circulating cortisol and enhancement of the acute phase protein response in vitamin $\mathrm{C}$ supplemented ultramarathon runners. Int J Sports Med 22: 120-126, 2001.

28. Petersen EW, Ostrowski K, Ibfelt T, Richelle M, Offord E, Halkjaer-Kristensen J, and Pedersen BK. Effect of vitamin supplementation on cytokine response and on muscle damage 
after strenuous exercise. Am J Physiol Cell Physiol 280: C1570_ C1575, 2001.

29. Piercy RJ, Hinchcliff KW, DiSilvestro RA, Reinhart GA, Baskin CR, Hayek MG, Burr JR, and Swenson RA. Effect of dietary supplements containing antioxidants on attenuation of muscle damage in exercising sled dogs. Am J Vet Res 61: 14381445, 2000.

30. Rokitzki L, Logemann E, Sagredos AN, Murphy M, WezelRoth W, and Keul J. Lipid peroxidation and antioxidative vitamins under extreme endurance stress. Acta Physiol Scand 151: 149-158, 1994.

31. Sanchez-Quesada JL, Jorba O, Payes A, Otal C, SerraGrima R, Gonzalez-Sastre F, and Ordonez-Llanos J. Ascorbic acid inhibits the increase in low-density lipoprotein (LDL) susceptibility to oxidation and the proportion of electronegative LDL induced by intense aerobic exercise. Coron Artery Dis 9: 249-255, 1998.

32. Schwager J and Schulza J. Modulation of interleukin production by ascorbic acid. Vet Immunol Immunopathol 64: 45-57, 1998.

33. Sen CK and Roy S. Antioxidant regulation of cell adhesion. Med Sci Sports Exerc 33: 377-381, 2001.
34. Thompson D, Williams C, Kingsley M, Nicholas CW, Lakomy HKA, McArdle F, and Jackson MJ. Muscle soreness and damage parameters after prolonged intermittent shuttlerunning following acute vitamin $\mathrm{C}$ supplementation. Int $J$ Sports Med 22: 68-75, 2001.

35. Vider J, Lehtmaa J, Kullisaar T, Vihalemm T, Zilmer K, Kairane C, Landor A, Karu T, and Zilmer M. Acute immune response in respect to exercise-induced oxidative stress. Pathophysiology 7: 263-270, 2001.

36. Vina J, Gomez-Cabrera M, Lloret A, Marquez R, Minana JB, Pallardo FV, and Sastre J. Free radicals in exhaustive exercise: mechanisms of production, and protection by antioxidants. IUBMB Life 50: 271-277, 2000.

37. Washko $\mathbf{P}$, Rotrosen $\mathbf{D}$, and Levine $\mathbf{M}$. Ascorbic acid in human neutrophils. Am J Clin Nutr 54, Suppl: 1221S-1227S, 1991.

38. White A, Estrada M, Walker K, Wisnia P, Filgueira G, Valdes F, Araneda O, Behn C, and Martinez R. Role of exercise and ascorbate on plasma antioxidant capacity in thoroughbred race horses. Comp Biochem Physiol A Mol Integr Physiol 128: 99-104, 2001.

39. Wolf G. Uptake of ascorbic acid by human neutrophils. Nutr Rev 51: 337-338, 1993. 